\title{
A CRITICAL REVIEW OF \\ THE SINGAPORE ENGLISH LANGUAGE SYLLABUS AS AN ADVANCE SYLLABUS IN ENGLISH LANGUAGE TEACHING (ELT)
}

\author{
Imam Munandar \\ IAIN Takengon, Aceh Tengah, Aceh \\ Email: imameducator@gmail.com
}

\begin{abstract}
The syllabus function as a framework that provide a national standard from which teachers gain a clear target of teaching English in schools. This research is a descriptive study by which it critically reviews the English language syllabus in Singapore, as an advance syllabus at time. The instrument of the review is a set of syllabus review outlined by Chew. This research has found the at syllabus is seen to be organized around the functional approach which necessitates the language in use. Besides, it conceptualizes language as an integration of linguistics, sociocultural, discourse and strategic competences. Teaching and learning leaning language is heavily put on learning process. It sees language acquisition involves certain processes and strategies, and thus teacher should focus on them. The syllabus implementation faces some challenges. Some teachers have different belief and values from the syllabus and resist the adoption. While the syllabus prescribes the communicative approach, they retain structuralism and behaviorism in teaching and learning the language. This situation is worsened by some technical issues. Some heads of department in schools have weak socialization of the syllabus in their schools, leading it unnoticed by teachers. Some textbooks fail to comply with the approach prescribed in the syllabus and thus demand a larger effort from teachers to select textbooks that accurately reflect the syllabus.
\end{abstract}

Keywords: Chew's Critical Review of Syllabus, English language syllabus, English Language Teaching

\begin{abstract}
Abstrak: Fungsi silabus sebagai kerangka kerja yang menyediakan standar nasional supaya para guru mendapatkan target yang jelas untuk mengajar bahasa Inggris di sekolah. Penelitian ini adalah penelitian deskriptif yang mengkaji silabus bahasa Inggris secara kritis di Singapura, sebagai silabus lanjutan pada saat itu. Instrumen ulasan adalah seperangkat tinjauan silabus yang digariskan oleh Chew. Penelitian ini menemukan bahwa silabus diorganisir dengan pendekatan fungsional yang mengharuskan bagaimana bahasa digunakan. Selain itu, bahasa dikonsepkan sebagai integrasi linguistik, sosiokultural, wacana dan kompetensi strategis. Mengajar dan belajar bahasa sangat bergantung pada proses belajar. Hal ini terlihat dari penguasaan bahasa melibatkan proses dan strategi tertentu, dan dengan demikian guru harus fokus pada strategi tersebut.Sementara itu, implementasi silabus menghadapi beberapa tantangan. Beberapa guru memiliki kepercayaan dan nilai yang berbeda dari silabus dan menolak untuk di adopsi. Ketika silabus menentukan pendekatan komunikatif, mereka mempertahankan strukturalisme dan behaviorisme dalam mengajar dan belajar bahasa. Situasi ini diperburuk oleh beberapa masalah teknis. Beberapa kepala departemen di sekolah memiliki sosialisasi silabus yang lemah di sekolah mereka, sehingga tidak diperhatikan oleh guru. Beberapa buku teks gagal mematuhi pendekatan yang ditentukan dalam silabus dan karenanya menuntut upaya yang lebih besar dari guru untuk memilih buku teks yang secara akurat yang mencerminkan silabus.
\end{abstract}

Kata Kunci: Analisa kritis silabus Chew, Silabus Bahasa Inggris, Pembelajaran Bahasa Inggris

\section{INTRODUCTION}

The history has noted that the educational curriculum has experienced changes from time to time. These changes are in most cases realized in the curriculum innovation. It is defined as "proposals for qualitative change in pedagogical materials, approaches, and values that are perceived as new by individuals who comprise a formal (language) 
education system" (Markee, 2001: 120). As a curriculum innovation is shaped by beliefs, values and conceptualizations of various groups involved, it is interesting to look at what concepts and whose beliefs are included and excluded from the curriculum. These beliefs are crucially concerned with language and language learning as well as its educational purpose. Jackson (1992, as cited in Graves, 2008: 149) point out that curriculum is "the product of someone's reasoning about what education is, whom it should serve and how".

He goes on to describe that a curriculum will only serve the interests of particular groups and at the same time omit those of others. On the surface level, it simply appears to us that a curriculum is a thick document consisting of contents and method that we are going to use in order to achieve the intended goal of education. However, we need to be informed that there are a complex processes from the planning and design to construction and implementation. Indeed, a curriculum can be seen as a compromise product that considers many individual and institutional interests which include e-governments and schools as the educational policy-maker, teachers as the professional practitioners and students themselves as to whom the curriculum is substantially targeted.

\section{LITERATURE REVIEW}

As its name indicates, the Singapore English language syllabus was introduced in year 2001 by the Ministry of Education in Singapore for primary and secondary schools. It is the syllabus that is applied in national level of the country. The former consist of a 4year foundation stage from Primary 1 to 4 and a 2-year orientation stage from Primary 5 to 6. The overall aim of primary education is to give students a good grasp of English language, Mother Tongue and Mathematics. The latter consists of 4-5 years of education which places students in the Special, Express, Normal (Academic) or Normal (Technical) course (the Ministry of Education Singapore, 2010). The syllabus contains the overview of the curriculum, aims, philosophy of language underlying the syllabus, principle of language learning and teaching, main features of the syllabus, place of national initiative in the syllabus, learning outcomes, and assessment guide.

The syllabus is taught in mainstream classroom. English language gains its importance in Singaporean schools as it is a medium of instruction for all subjects in schools excluding Chinese, Malay, and Tamil languages subjects (Lin, 2004). Besides being as classroom instruction language, English is also a subject Singaporean school. Lin (2003) identifies that the need of English as a subject taught in schools lies on two 
reasons. First, although English is a lingua franca for multiethnic identity in Singapore, the majority of populations do not speak it at home. One year before the syllabus introduction, a survey found that only $23 \%$ Singaporean frequently speak English at home (Leow, as cited in Lin, 2003). Secondly, although English becomes second language, type of English used among Singaporeans is informal, which cannot be found in English textbooks taught in schools, and thus this sort of English cannot be used in work or business purpose, and in international or multi-national context which is central for Singapore. These situations have led the government to take English to be a subject in schools, which an ultimate goal of enabling students to develop their English into more formal and internationally standardized form.

It is shown that the revitalization of three ethnical languages (Chinese, Malay, and Tamil) is Singapore is not done in form of providing bilingual education for students in which there are two language used in the classroom. The maintaining of literacy in those ethnical languages is conducted by the provision of those languages as independent subjects which are taught to students. For these thee language subjects, students are taught by using the related language. For example, in Chinese language classroom, students are taught about Chinese language as a subject with Chinese language as the medium of instruction.

The context of English learned in Singaporean schools is English as Lingua franca (ELF). "The context for learning English is multi-cultural Singapore, Asia and the rest of the world. Pupils will be exposed to the cultures in Singapore as well as to other cultures outside Singapore, and to the different standard varieties of English spoken in other parts of the world" (Syllabus document, 2001: 1). This context considers learning varieties of English and without prescribing one of English dialect of inner-circle English speaking country. ELF is believed to be suitable with commercial and multicultural Singapore context. Economically, Singapore has commercial relationship mainly with non-English speaking countries, and therefore, there is no need to adopt one of inner-circle English dialects. In teaching ELF for students, the syllabus encourages teachers to teach how to speak with people from different religion, culture and belief. The learning outcome in this respect is "Interact effectively with people from own or different culture(s) / religion(s)" (syllabus document, 2001). This suits the context of Singapore in which its population is made up from several racial backgrounds and religions, such as Chinese, Malay, Indian and Tamil with different religious orientations. 


\section{RESEARCH METHODOLOGY}

The purpose of this research is to critically review the Singapore English language Syllabus. The review is carried out by employing descriptive research, by which the syllabus will be described against a set of determined criteria. The instruments used are a set of review criteria set by Chew (2005). The criteria consists of the description of current status and position of the syllabus, and the identification of changes that it has gone through and the innovation linked to the document. Also, the writer will illustrate the organizing principle on which the syllabus is based. Besides, the theoretical and philosophical basis of language and language learning that underpin the syllabus will be discussed. The writer will provide comments on how the curriculum has considered the context in which it is applied and the assessment instrument embodied with it. Lastly, I will demonstrate the external factors that might influence the syllabus design and identify any problematic issues that occur in the syllabus implementation.

\section{RESEARCH FINDINGS AND DISCUSSION}

\section{Innovations in the syllabus}

According to Lin (2003) the syllabusis a renewal form from the 1991 syllabus and reflects a fair departure from the integrative approachto the genre-based approach to syllabus. While the formerstrongly necessitates the language fluency, the latter follows the communicative language teaching which is incorporated with grammatical pedagogy. As a result, grammar is taught in contextualized and meaningful topics. For instance, as the syllabus is organized around genre-based approach, the grammar is taught in terms of particular features that help a particular genre achieve its purpose. The innovation of 2001 syllabus is also reflected in providing theoretical and philosophical basis for language and language learning. It contains a clear description of language and language learning theories on which it is based. Unlike the syllabus 2001, the previous syllabus which was implemented from 1991 to 2001 is found to be absent from providing theoretical and philosophical basis underpinning the syllabus. Apart from this, as it marginalizes the role of grammar, it fails to prepare students to use English for education. Other central innovation in the new syllabus is that it unifies the syllabus from primary schools and secondary schools which is integrated as a whole and presented in a single document. This makes the syllabus to be coherent and help two levels of schools to have 
a clear picture of what students have learnt in primary schools and what they should learn in secondary schoolwith regard to continuity of language teaching.

Following Havelock' term (Havelock, as cited in Markee, 2001: 123) on models and strategies of changein curriculum innovation, the diffusion-of-innovations theory can explain the syllabus 2001. The theory is described as a change in curriculum that involves various stakeholders and is always relevantto language teaching. Within this theoretical perspective, the syllabus can be further assigned to innovation model of Research, Development and Diffusion (RD and D). As its name suggests, this model recognizes that a curriculum innovation involves initial research which is followed by development and implementation by potential adopters. Furthermore, in terms of innovation strategies, the syllabus can be classified into power-coercive innovation strategy. Markee (2001) mentions that this strategy occurs when RD and $\mathrm{D}$ is influenced bypolitical, administrative and economic motivations. He explains that this strategy takes place when the innovation is initiated by government through the ministry of education develops a new syllabus applied nationwide.

Relating to 2001 syllabus, as Lin has described, it is a product accomplished by Singaporean Ministry of Education to provide language teachers a framework as a standard, within which they can develop their materials and method in teaching practice. Before come up with the syllabus 2001, the government has gone through several works in developing the new syllabus. This includes need assessment which has been carried out which involve stakeholders such as researchers, educators, teachers and parents. Need assessment is important part for the sake of accountability and it provides the response to the demand of evidence of the relevance and outcomes of educational program (Richards, 1984: 26-32). The syllabus 2001 can be seen as the model of innovation that emphasizes collaborative partnership among stakeholders. Unlike the previous syllabus that are much prescriptive, the broader scope of stakeholders involved in developing the syllabus 2001 leads it to be seen as collaboration. The government treats the syllabus as not rigidly prescriptive and gives schools/teachers freedom to develop local syllabus that suit their local context. It sees teachers as professionals, not technicians. In this case, the syllabus 2001 serves as guidance which is only applied in broader definition of standard, learning outcomes and assessment guidance. However, in defining these standards, learning outcomes and assessment instrument, there are a number of external factor such as 
political and economical that have influenced the decisions, and this will be discussed later on in the following section.

The innovation in syllabus 2001 is also seen about individualization of students' learning. Individualization is defined as "a system in which education is tailored to fit each individual" (Kostogriz, 2010). In the syllabus 2001, one of the teaching learning principles is said to be " learner centeredness, in which the learner is at the centre of the learning process. Teaching approaches, lessons and curriculum materials are differentiated according to learners' needs and abilities" (Syllabus Document, 2001: 4). This shows the syllabus demand teachers to be sensitive to the differences students bring with them and thus treat them accordingly. Another aspect of this individualism is the active participation in the classroom. Teachers are viewed as not knowledge transmitter, but facilitators that scaffold students in learning the language.

\section{The organizing principle of the syllabus}

In order to identify the principle around which the syllabus is organized, it is helpful to look at how the syllabus conceptualizes the language. By being able to communicate in English, the syllabus maintains that "pupils need to know how to communicate fluently, appropriately and effectively in internationally acceptable English. They need to understand how the language system works and how language conventions can vary according to purpose, audience, context and culture, and apply this knowledge in speechand writing in both formal and informal situations" (Syllabus Document, 2001: 4). In the document in page 5 in the main feature of the syllabus, it is obviously stated that the kind of language used in the syllabus is language in use (functional language). It identifies three major language areas, which involves language for information, language for literary response, and language for social interaction. In teaching grammar, the syllabus also demands teachers to teach it in a meaningful situation. Lim (2003: 233) in line with this idea mentions that syllabus 2001 is a "language use syllabus which seeks to teach pupils to communicate fluently, appropriately and effectively as well as to understand how the language system works and how language conventions vary according to purpose, audience, context, and culture". Similarly, Lin (2003) points out that syllabus 2001 use the organizational principle of areas of language use in realizing its philosophy and principle, as opposed to inventory of grammatical items and sentence structure. 


\section{The theoretical approach of language of the syllabus}

It is observed that the language being conceptualized in the syllabus follows Swain's model of language competence, which integrates linguistics, sociocultural, discourse and strategic competence. More precisely, it follows the systemic functional grammar (SFG) and genre-based approach. These approaches can be identified in the philosophy of language underlying the syllabus (Syllabus Document, 2001: 3), which mention (1) Language is a system for making meaning, (2) It is a means of communication and expression, (3) Language use is determined by purpose, audience, context and culture, (4) Language has a grammar and linguistic structures and patterns, which can be used to create various discourse forms or text types depending on the linguistic choices made.Learners have to be taught how to make these linguistic choices to suit purpose, audience, context and culture. The first point of the language philosophy can be assigned to SFG. Bloor \& Bloor (2004) describe SFG sees language as system of meaning. Unlike Formal grammar perspective, ittries to account for functional aspect of grammar of the language not separated from meaning. The approach maintains that when people use language, they are trying to construct the meaning, not form.

Furthermore, the second to the fourth points emphasizes the language as a medium of communication, in which they are used according to contexts and cultures. These points see the language to be tied to context, which cannot be learnt in isolation. These elements are realized in various forms of genres presented in the syllabus. The syllabus provides specific types of genre/ text types which are used for different purposes with difference audience in real-life context that need to be taught. Derewianka (2003) points out that genre-based approach in language teaching is characterized by those aspects of language that focus on text, purpose, meaning, context, and culture. She explains that rather that dealing with discrete stretch of a text, the approach put the emphasis on the creationof meaning at the level of the whole text. Also, the approach sees the language use as goal-oriented. Genres enable people within a particular culture to achieve the aim of communication.

It is also observed that syllabus 2001 provides various genres which are realized in several types of texts. Students are taught these texts and are expected to identify different purposes that they can fulfill to different readers in real life situation (Lin, 2003). The text types include exposition, explanation, recount, instruction, explanation, and information report. Furthermore, teaching grammar for students is intended to enable 
students to recognize various genres by identifying grammatical features associated with a particular text. For example, connectors of time or cause and effect, passive voice and simple present tense are grammatical features identified as typical in genre of “explanation" (Lin, 2003).

\section{Theory that underpin language learning in the syllabus}

There are six underlying principles mentioned in the teaching and learning principle in the syllabus (Syllabus Document, 2001: 4). They are (1) Learner centeredness, (2) process orientation, (3) integration, (4) contextualization (5) spiral progression and (6) interaction. Lin (2003) describes learner centeredness as when teaching and materials are differentiated based on students' needs and abilities. Process orientation implies that teaching should focus on learning skills, rather that learning products. Integration and contextualization require teachers to use the materials and lessons with real life, in which all of language work in terms of real life purposes. Spiral progression is described as a revisiting of what have been taught at increasing level of difficulty. Finally, interaction is defined as encouraging students' active involvement in leaning process both with teachers and their peer.

From those principles, it can be expected that the syllabus is influenced by cognitive and interactionism perspectives of language learning. Cognitive approach, as is especially identified from point 1 until 4, believes that the focus of teaching is on learning itself. This process is enhanced when learners learn language in meaningful situations. The theory focuses on the processing of language data-how language data is processed in sequential development. This approach recognizes that learning something new, including language includes a universal mechanism. Furthermore, interactionism (especially shown by point 6) maintains that learning language happen as language data interacts with the learners' internal language mechanisms. This approach necessitates the role of interaction for students in acquiring a new language.

Lin (2003) suggests that the syllabus emphasizes the pedagogical approach according to constructivist practice that necessitates observing and thinking about how language is used, as a basis for effective, intelligent and creative use. The approach rejects the passive learning of described as rules, or mere communicative practice without critical cognitive process. This assumption has led the syllabus 2001 to incorporate communicative and grammatical approach in language learning. 


\section{Assessment instrument within the syllabus}

The assessment provides a broad scope for teachers to develop their own assessment tasks with adhere to the points stated in the syllabus assessment guidance. The aim of assessment in the syllabus is "to provide information on what a pupil can do as an English Language user / learner in relation to the syllabus and its Learning Outcomes. This information will enable teachers to improve pupils' learning and the quality of instructional programmes" (Syllabus Document, 2001: 141). The assessment provides teachers with a bigger autonomy in deciding and designing their own assessment tasks according to their context of teaching. The assessment is based on broad-based and multi dimensional approach to assessmentwhich follows the communicative language teaching, that is it does not only test students in form of paper and pencil test, but also by performance test in which students are required to communicate.

There are four principles of testing embodied in the assessment, involving validity, reliability, discrimination and transparency. Teachers, in validating a test should be informed about these principles. The assessment serves as either guides or framework within which teachers concentrate in designing the assessment tasks of their own. The assessment provides teachers with a clear direction on how to design the test which reflect the three areas of language used, genres and grammar that are prescribed in the syllabus. The guidance on how to decide whether or not students are able to attain the learning outcomes outlined in the syllabus is also given to teachers. It also explicitly gives teachers some examples of assessment tasks on which teachers can rely on, such as port-folio, quizzes and teachers-students conferencing.

Moreover, the assessment prescribed in the syllabus allows teachers to assess students both formally and informally. Formative assessment (ongoing assessment) is purposed to help students in their development. This assessment has the ultimate goal as to improve the teaching and learning. In designing the formative tasks, and ensuring the appropriate utilization of the assessment, the syllabus assessment firmly discourages teachers to replicate the formal assessment which is intended to rank and measure students' achievement. Meanwhile, the formal assessment grants little authority for teachers since it is designed and carried out by external testing body which is called the Research and Testing Division (RTD). However, teachers will be able to access the information on students' achievement for purposes of placement, steaming and students 
promotion. This formal assessment is conducted in the end of semester which is intended to measure the achievement of students.

Nevertheless, while the syllabus is said to be learner-centeredness, there is only little space for students themselves in terms of participating in the assessment, especially formative assessment process. In the syllabus 2001, teachers are only those who are authorized in assessing students. However, as a form of learners' autonomy centralized in student- centeredness, students can be empowered to be more self-aware of their language ability by introducing self and peer assessment. In these assessments, students are trained to accept greater responsibility for their own learning, and they can learn as much from each other as they can from the teacher (Hill, 2009).

\section{External influence on syllabus}

Lin (2003) reports that the recent syllabus is influenced by the work of Halliday in types of genres. There are in many parts of syllabus guides citations with reference to Halliday definition and categorization of genres. Lin claims that the initial influence of the Halliday approach is traced to when he and other functional linguist taught at National University of Singapore and SEAMEO RELC in the country. He predicts that the students who graduated from their schools and then became curriculum developers have influenced the innovation of the 2001 syllabus. Also, many seminars on curriculum development were featured by functionalist linguists. Most convincingly, as Lin reports, the $26^{\text {th }}$ International Systemic Functional Institute and Congress was held in Singapore which is aimed at introducing SFL and its approach to genre to Singaporean educational institutions. These situations are expected to have fair influence on the development of the syllabus under this review.

Chew (2005) in his paper mentions that syllabus "represents the adherence to some set of sociolinguistic beliefs regarding education. It can be viewed as a political manifesto because it reveals the designer's views on authority and status". In Singapore context, he shows that syllabus 1999 which emphasized vague conceptualization has brought about the deficiency of standard written form of English among students in the country. This situation has had political and economic implications. There is a political concern over what have been considered as declining standards in written English which negatively affect Singapore's global competitive ratings. To improve this situation, the government decides to give the explicit teaching of grammar in the 2001 syllabus. Apart from this, Chew suggests that the innovation initiated by the government is often economically 
motivated. He claims that formal assessment situated in the syllabus has been influenced by job market. He goes on to explain that the formal examination will give students grades on their achievement which are used to decide whether or not they are eligible in a job position. The formal examination held by external body implies that the government takes the accountability of students' final achievement seriously in order to ensure them to be competence and successful in working places.

Chew (as cited in McKay, 2003) has found that learning English among Singaporean involve a conscious choice who believe that English is plays a significant role in the country's economic survival. Singapore is believed to be one of the countries that have a strongest and sustainable economy and with the most advanced technology in south East Asia. It seems that the government's purpose of empowering the country has influenced the English syllabus. The government is concerned with the significance of English for the country's development, in which English enable Singaporean to be able to access information written in Englisha variety of studies including science, technology andcommerce. As a result, the government put English as language for information in the syllabus. Its concrete influence to the syllabus is found where it puts English as the "language for information" among three areas of language use.

Another influence is with regard to university admission examination. It is observable in the syllabus that the genres which are taught to students are increasingly relatively complex as they are in higher level of class. Lin (2003) exemplifies that since students will deal with academic writing in forms of Information reports, Explanations, and Expositions in tertiary education, the syllabus place a strong emphasis on these genres in higher classes. From this, it is expected that the syllabus is constructed to prepare students for use of English which is typically found in university level of education.

\section{Syllabus implementation and its problem}

Verspoor (1989, as cited in Carless, 2001) points out that teachers training and support are central in the preparation of teachers to implement a curriculum innovation. Carless (2001) suggests that teachers are a crucial factor whether or not curriculum is successfully implemented. For a new curriculum to be successful, he further indicates that it is vital for teachers to have comprehensive understanding both underpinning theoretical basis and the practical application of innovation in the classroom. To achieve this, Lin (2003) reports that in the implementation of syllabus 2001, two measures have 
been conducted to prepare teachers to implement the syllabus which were carried out by the Ministry of Education, in alliance with the University of Cambridge Local examination Syndicate. The first is the provision of training for primary and secondary schools teachers in purpose of informing them the philosophy behind the new syllabus and help them to evaluate and design lesson to meet the syllabus aim. In the practical level, teachers are trained how to approach teaching in accordance to the syllabus, especially how teaching grammar can be carried out to help students to identify various text types.

The second step taken, according to Lin, is the provision of Guides to the English Language Syllabus 2001 Primary 1-6 and the Guide to the English Language Syllabus 2001 Lower and Upper Secondary. These guides give teachers the specific information about techniques and activities for teaching various skills areas including oral communication, reading comprehension, text types and grammar. Besides, the guides provide a clear direction on planning the school's specific instructional programme based on the syllabus.

Lin (2003) in his field study on the implementation of syllabus 2001 has reported that there are some problems regarding the theory and practical application among stakeholders. He found that there emerge some kinds of resistance to adopt the recent syllabus. This is caused by the different view between some teachers and government about philosophical perspective on language and language learning. In spite of complying with the new syllabus, many teachers retain the structural nature of the language and behaviorism that consider Grammar as a fundamental language element to be taught to students. Lin further shows that other challenges in implementing the syllabus rest on some course trainers themselves, who have no complete understanding of the syllabus 2001 they are introducing. It is observed that those trainers are deviant from socialization of the communicative approach inscribed in the new syllabus, they tend to prescribe traditional notions of grammar teaching. These examples reveal that implementing curriculum is one of the difficult stage through which a change might take place since the shared philosophy, agenda and purpose among stakeholders are difficult to achieve.

If the last paragraph describes the beliefs and values impeding the curriculum innovation to take place, the following problem found by Lin (2003) in his observation is regarded with the practical issues in carrying out the innovation implementation. He found that while the guides of new syllabus are distributed to schools, many head of the 
department do not make the readily for teachers, leaving teachers unaware of the presence of those guides in their schools. Besides, there is also a concern on textbooks. Lin indicates that as there are huge options for teachers to select appropriate textbooks made readily in markets, teachers are required to employ a greater professional discernment in choosing the textbooks. The situation is worsened where some textbooks have lack understanding of thinking and approach of the new syllabus. Also, Teo (as cited in Lin, 2003: 243) has shown, some textbooks do not substantially provide materials friendly to its philosophical basis, but they are rather "cosmetically" representing the syllabus. These situations are expected to have compromised the effectiveness of new syllabus implementation in the country.

\section{CONCLUSION}

Even though the syllabus encompasses a strong influence from the government, it gives teachers extra space for teacher to develop their teaching design to suit their context of teaching. The syllabus function as a framework that provide a national standard from which teachers gain a transparent target of teaching English in schools. Based on Chew's set of syllabus rview, the Singapore English syllabus is seen to be organized round the functional approach which necessitates the language in use. Besides, it conceptualizes language as an integration of linguistics, sociocultural, discourse and strategic competences. Teaching and learning leaning language is heavily placed on learning process, it sees language acquisition involves certain processes and methods, and thus teacher should specialise in them. The syllabus implementation faces some challenges. Some teachers have different belief and values from the syllabus and resist the adoption. While the syllabus prescribes the communicative approach, they keep structuralism and behaviorism in teaching and learning the language. This case is worsened by some technical issues. Some heads of department in schools have weak socialization of the syllabus in their schools, leading it unnoticed by teachers. Some textbooks fail to fits the approach prescribed within the syllabus and thus demand a bigger effort from teachers to pick out textbooks that accurately reflect the syllabus.

Furthermore, it can be concluded that, the remaining issue of the syllabus 2001 is about its implementation. While the syllabus has been designed to develop students' English competence, and fit the context of multicultural Singapore and its future goals, there is still problem in the level of practical application in schools and classrooms. The 
syllabus 2001 has showed how the teachers' resistance obstructs the innovation enactment in the classroom. This situation reveals that teachers have a powerful role whether or not for an innovation to be successful. In the future, the government as the curriculum developer should bear in mind that, changing the curriculum is also changing the mind set of stakeholders, especially teachers. The outcome of innovation is not an overnight matter, and thus it should focus on the level of curriculum innovation.

\section{REFERENCES}

Bloor, T., \& Bloor, M. (2004). The functional analysis of English. London: Hodder Education.

Carless, D. R. (2001). A case study of curriculum implementation in Hong Kong. In DR Hall and A Hewings (Eds.), Innovation in English language teaching (pp.263-274). Oxon: Routledge.

Chew, P. G. L (2005). Change and Continuity: English Language Teaching in Singapore. Asian EFL Journal, 7(1), 1-21.

https://www.asian-efl-journal.com/main-editions-new/change-and-continuityenglish-language-teaching-in-singapore/

Derewianka, B. (2003). Trends and issues in Genre-Based approaches. RELC Journal, 34 (2), 122-154.

https://doi.org/10.1177\%2F003368820303400202

Graves, K. (2008). The language curriculum: a social-contextual perspective. Language teaching, 41(2), 147-181.

doi:10.1017/S0261444807004867

Hall, D. R., \& Hewings, A. (2001). Introduction. In DR Hall and A Hewings (Eds.), Innovation in English language teaching (pp.1-5). Oxon: Routledge.

Hill, K. (2009). Self and peer assessment and assessment of young learners. Topic 10 in the Study Guide of English Language Testing and Assessment 2009. Australia: Deakin University.

Kostogriz, A. (2010). The diffusion of innovation in language teaching. Topic 8 in the Study Guide of Innovation in Language Curriculum 2010. Australia: Deakin University.

Lin, B. (2002). English as international language: discourse as an answer to what to teach \& how to teach it (pp.1-16). Conference Proceeding of The $7^{\text {th }}$ Annual Conference Pan-Pacific Assosiation Of Applied Linguistics. http://www.paaljapan.org/resources/proceedings/PAAL7/pdfs/01benedict.pdf

Lin, B. (2003). English in Singapore: an insider's perspective of syllabus renewal through a Genre-Based approach. RELC Journal, 34 (223), 223-246. https://doi.org/10.1177\%2F003368820303400206 
Markee, N. (2001). The diffusion of innovation in language teaching. In DR Hall and A Hewings (Eds.), Innovation in English language teaching (pp.118-126). Oxon: Routledge.

McKay, S. L. (2003). EIL curriculum development. RELC Journal, 34(1), 31-47. https://doi.org/10.1177\%2F003368820303400103

Ministry of Education Singapore (2010). Syllabus 2001. from https://www.moe.gov.sg/docs/defaultsource/document/education/syllabuses/english-language-andliterature/files/english-primary-secondary-express-normal-academic.pdf. Retrieved October 3, 2010.

Richards, J. C. (1984). Language Curriculum Development. RELC Journal. 15(1), 1-29. https://doi.org/10.1177\%2F003368828401500101 